\title{
COMPLICATIONS OF THE FIRST STAGE OF LABOUR TREATED BY VACUUM EXTRACTION
}

\author{
M. A. Austin, M.B., M.R.C.O.G. \\ Senior Registrar, Obstetric Department, Lewisham Hospital, London, S.E.1 3
}

THE vacuum extractor or ventouse has been widely used on the Continent as an alternative to forceps delivery for about 15 years, but in the British Isles the first modern report of its extensive use was by Chalmers and Fothergill (1960). An unsuccessful attempt to effect delivery by suction, using a cupping glass, was recorded as early as 1706 . Simpson, in 1849 , wrote a treatise 'On a suction-tractor, or new mechanical power, as a substitute for the forceps in tedious labours'. Since that time there have been various arbitrary designs of suction apparatus, using rubber or metal cups. The mathematical calculations and experiment essential to the designing of a technically efficient suction apparatus were carried out by Malström (1954, 1957). The instrument now used in England is based on his design.

Since October 1960 the ventouse has been used in this hospital for complications of the first stage of labour, so obviating a Cæesarean section in many cases. It has not been adopted for all forceps deliveries as Kielland's forceps are felt to be of more practical use to the housemen in their later careers as general practitioners.

In the past $2 \frac{1}{2}$ years the ventouse has been applied, prior to full dilatation, on only 32 occasions in over 4,000 deliveries, an incidence of $0.7 \%$ (Table I). The indications, results, and dangers will be discussed.

\footnotetext{
Apparatus

The vacuum extractor consists of a metal traction cup which is connected to a traction handle by means of a metal disc within the cup and its attached chain. The chain is maintained in position by a pin inside the traction handle. Suction tubing joins the cup to the traction handle and thence to the vacuum bottle, where a vacuum gauge records the pressure in $\mathrm{kg} . / \mathrm{cm} .{ }^{2}$. The hand pump, which creates the vacuum, is connected to the bottle by further rubber tubing and metal connector tubing containing a screw-release valve. There are three sizes of traction cup, VE 30,40 and 50 , all with a standard depth of $20 \mathrm{~mm}$. The two larger cups have a rotation knob which is directed towards or over the occiput during application.

Leaking around the vacuum bottle bung can be troublesome but after the production of a suitable vacuum a gateclip can be screwed firmly onto the tubing. Another cause
}

TABle I

Summary OF Deliveries

\begin{tabular}{l|c|c}
\hline & $\begin{array}{c}\text { Number of } \\
\text { Cases }\end{array}$ & $\begin{array}{c}\text { Stillbirths and } \\
\text { Neonatal Deaths } \\
\text { (uncorrected) }\end{array}$ \\
\hline Deliveries & 4,377 & $201(4.6 \%)$ \\
\hline Cæsarean sections .. & 259 & $17(6.5 \%)$ \\
\hline \begin{tabular}{l} 
Forceps deliveries .. \\
\hline $\begin{array}{c}\text { Ventouse deliveries } \\
\text { (includes forceps) }\end{array}$
\end{tabular} & 398 & $17(4.3 \%)$ \\
\hline
\end{tabular}

of difficulty in maintaining a vacuum is leaking due to a worn washer beneath the pin in the traction handle. The apparatus is easily dismantled for sterilizing by boiling. The vacuum bottle, protected by a plastic covered metal frame, can be placed on or hung from a trolley.

\section{Principles}

Production of a vacuum sucks adjacent scalp tissue into the cup, creating an 'adhesive force'. The rim of the cup has a smaller circumference than the cavity of the cup so that the skin is drawn in at a suitable reference angle, thus preventing detachment. The effect of suction and traction is distributed to the cup edge. Providing the suction force is greater than the traction the cup will remain attached. A traction force between 9 to $22 \mathrm{~kg}$. can cause detachment. Traction must be applied at right angles to the centre of the site of attachment, for maintenance of an oblique pull reduces the 'adhesive force'.

Malström (1957) considered that the increase in intracranial pressure during suction is negligible, as the scalp tissue drawn into the cup can move independently of the cranium and galea. This, however, is disputed by de Boer (1960) who found that application of the ventouse, without traction, to the scalp of a fresh stillbirth raised the spinal pressure from $\circ$ to $25 \mathrm{~cm}$. He attributed this result to the lack of rigidity of the baby's cranium.

Using external tocometry, Malström demon- 
strated that intermittent traction exerted by the vacuum extractor synchronous with uterine contractions prior to full dilatation of the cervix, stimulates uterine contractions at the internal os level. There is a close correspondence between the strength of traction and uterine response.

\section{Application}

A preliminary pudendal block with $0.5 \%$ or $1 \%$ lignocaine was used in all cases except one. General anæsthesia was used to replace an arm prior to application of the instrument.

The size of cup used depends on the degree of cervical dilatation. Sometimes a small introitus prevents insertion of the large cup and an early episiotomy is not advisable, since the delivery interval may exceed an hour. The medium cup has been most frequently used. The cup is inserted obliquely into the vagina and applied as close to the vertex as possible. The head tends to displace upwards in multigravidæ, particularly when above the level of the spines, but suprapubic pressure helps to control this.

The vacuum is slowly induced, as advised by Malström (1957), an initial vacuum of 0.2 $\mathrm{kg} . / \mathrm{cm} .^{2}$ being increased by 0.1 or $0.2 \mathrm{~kg} . / \mathrm{cm} .^{2}$ every two minutes, to a level of $0.6 \mathrm{~kg} . / \mathrm{cm} .^{2}$, so that detachment of the cup is less likely. During this process it is important to check that the cervix has not been drawn under the cup. The cervix may be freed easily by sweeping a finger between it and the head. The artificial caput thus raised is more conveniently termed 'chignon'. The $0.6 \mathrm{~kg} . / \mathrm{cm} .^{2}$ suction force is sufficient for the light traction necessary to stimulate uterine contractions until full dilatation. Initially, continuous light traction is more effective in cases of inertia. In primigravidæ, a vacuum of $0.8 \mathrm{~kg} . / \mathrm{cm} .^{2}$ is necessary to allow strong traction.

\section{Indications and Results}

The indications for interference in the first stage of labour are shown in Table 2. As in other series (Snoeck, 1960; Lillie, 1960; Fothergill and Chalmers, 196r; and Willcocks, 1962), the commonest indications are delay and fotal distress. Chalmers (1960) advocates use of the ventouse after failed conservative management of prolonged labour.

Patients with delay in labour formed the largest group delivered with the ventouse and include a large proportion of cases of prolonged labour (by arbitrary definition over 36 hoursStandard Maternity Hospital Report Committee). The ventouse was only applied with the cervix less than half-dilated in one of the nine primigravidæ, full dilatation being reached in about an hour but as no descent occurred on traction,
TABle 2

Indications for APPlication of Ventouse

\begin{tabular}{|c|c|c|c|}
\hline \multirow{2}{*}{ Indication } & \multicolumn{2}{|c|}{ Number of Cases } & \\
\hline & Primiparæ & Multiparæ & Total $=$ \\
\hline $\begin{array}{l}\text { Delay in first stage } \\
\text { or uterine inertia }\end{array}$ & 9 & 5 & 14 \\
\hline Fœtal distress & 3 & 4 & 7 \\
\hline $\begin{array}{rrr}\text { Occipito - posterior } \\
\text { position } & \ldots & \ldots\end{array}$ & 5 & $\mathbf{I}$ & 6 \\
\hline 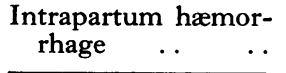 & 0 & 2 & 2 \\
\hline Malpresentation & $\mathbf{I}$ & I & 2 \\
\hline Maternal distress .. & $\mathbf{I}$ & $\circ$ & $\mathbf{I}$ \\
\hline
\end{tabular}

Kielland's forceps were applied. Rotation of the ct head could not be completed and there followed a difficult delivery with the head in an obliquece anterior position. The baby cried well but was응 later slightly cerebral. Only one of the primiparæwas delivered with the ventouse, traction being $?$ used for 55 minutes and the second stage lastinge

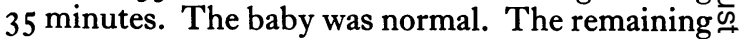
seven primiparæ were all delivered by force $3 \overrightarrow{0}$ for varying reasons, viz. detachment of the cư , non-rotation or descent of the head within minutes of full dilatation, and thick perineurn

On five occasions in multigravidæ, the ventouse was used for delay when the cervix was 2 to 4 을 fingers ( 3 to $6 \mathrm{~cm}$.) dilated. Wrigley's forceps were $\frac{\varnothing}{\varnothing}$ necessary once, as the baby was still not delivered $\varrho$ 25 minutes after full dilatation. This group $\overrightarrow{\vec{B}}$ included the child with cerebral damage, the 3 remainder being healthy. There was slight? abrasion and scalp bruising in two instances, the traction times being 20 and 75 minutes.

The group of occipito-posterior positions mostly had an additional reason for expediting delivery, such as maternal distress or pre-eclamptic toxæmia. The malposition had been noted early옥 in labour and the cervix was over half dilated $(8 \mathrm{~cm}$.). Only one of these primiparæ was successfully delivered with the ventouse, the remainder $\frac{}{2}$ requiring Kielland's rotation and forceps extractions, two being classed as difficult. It is $\tilde{N}$ important in this group to assess the pelvis as $N$ some cephalopelvic disproportion is often present. N

The time taken to deliver cases of fœtal distress $\omega$ varied from 12 to 70 minutes. Four of the babies were in good condition at birth and three were $a$ little limp, but only required mild resuscitation. Two primigravidæ had early foetal distress but as full dilatation was slowly acheived, forceps were then applied. One multigravida having only had 
TABle 3

Cervical Dilatation Related to Traction Time

\begin{tabular}{|c|c|c|c|c|c|}
\hline \multirow[b]{2}{*}{ Dilatation } & \multicolumn{2}{|c|}{ Primiparæ } & \multicolumn{2}{|c|}{ Multiparæ } & \multirow[b]{2}{*}{ Total } \\
\hline & No. & $\begin{array}{l}\text { Traction } \\
\text { time over } \\
30 \text { mins. }\end{array}$ & No. & $\begin{array}{l}\text { Traction } \\
\text { time over } \\
30 \text { mins. }\end{array}$ & \\
\hline $\begin{array}{c}2-4 \\
\text { dilated } \\
\text { dingers } \\
\text { to } 6 \quad \mathrm{~cm} .)\end{array}$ & 3 & 2 & 7 & 5 & 10 \\
\hline $\begin{array}{l}\frac{1}{2}-\frac{3}{4} \text { dilated } \\
(8 \mathrm{~cm} . \text { and } \\
\text { over })\end{array}$ & 10 & 5 & 6 & 2 & 16 \\
\hline $\begin{array}{r}\text { Rim of } \\
\text { cervix }\end{array}$ & 6 & 2 & 0 & 0 & 6 \\
\hline
\end{tabular}

a Cæsarean section previously, had forceps applied electively and the lower segment scar was examined and found to be intact. Snoeck (1960) suggests that grave fœtal distress is a disputable indication for vacuum extraction. However, in multigravidæ in the first stage of labour it is possible to deliver the baby more rapidly by vacuum extraction than by preparing for and performing a Cæsarean section.

The ventouse is certainly of value in the management of intrapartum hæmorrhage. The bleeding with each contraction in a twin pregnancy was effectively controlled by traction and living infants delivered. A Syntocinon drip was used to induce labour in a patient with Rhesus antibodies at 36 weeks as the cervix was 'unripe'. This was later followed by a I2-ounce blood loss and an irregular fotal heart rate. A severely affected infant was delivered with the ventouse, two exchange transfusions being needed.

The malpresentation encountered in both instances was an arm prolapsed alongside the head. A general anæesthetic was used during replacement of a recurrent arm prolapse in a primigravida and, although it took an hour to complete delivery, the infant needed only mild resuscitation. The other case followed surgical induction of labour at 36 weeks for Rhesus antibodies, the induction delivery interval being prolonged.

Other indications for interference have been recorded. Snoeck (1960) and Fothergill and Chalmers (196I) mention uterine scars from myomectomy or Cæsarean section. The same authors and Alment (1960) have used the ventouse for antepartum hæmorrhage of the accidental type and for placenta prævia.

\section{Fœtal Complications}

The time taken to effect delivery or to decide to apply forceps is related to the degree of cervical
TABLE 4

Fetal Complications Related to Traction Time

\begin{tabular}{|c|c|c|}
\hline Complication & $\begin{array}{c}\text { Traction } \\
\text { Up to } 30 \mathrm{mins} .\end{array}$ & $\begin{array}{c}\text { Time } \\
\text { Over } 30 \mathrm{mins} .\end{array}$ \\
\hline $\begin{array}{c}\text { Scalp trauma : abrasion } \\
\text { or bruise } \quad \ldots\end{array}$ & 5 & 2 \\
\hline $\begin{array}{l}\text { Infection or } \\
\text { ulceration } \ldots\end{array}$ & 0 & 3 \\
\hline Cephalhæmatoma & $\mathbf{I}$ & 0 \\
\hline Cerebral irritation & 0 & 3 \\
\hline Perinatal mortality .. & 0 & 0 \\
\hline
\end{tabular}

dilatation. When the cervix was three-quarters or less dilated in primigravidx, over 30 minutes' traction was required in half the cases. This again applies to multigravidæ, when the cervix is less than 4 fingers $(6 \mathrm{~cm}$.) dilated (Table 3$)$. The fœtal complications must be assessed in relation to these two factors.

In this series (Table 4 ), fotal complications occured on I I occasions. The three infants with cerebral irritation had associated scalp trauma and traction lasted over 30 minutes. The scalp abrasions were of a minor nature in seven cases and all were healed prior to discharge from hospital. Abrasions seemed to occur when the cup was detached during traction. There was circular scabbing of the scalp at the cup site in three cases, preceded by a scalp hæmatoma and bruising in two babies and blistering noted at birth in one. The former had bald areas in this region at followup. Beneath the scabs of the latter infection developed and an abcess formed in the right occipital region, about $I \frac{1}{2}$ inches away from the traumatised area. The abscess required incision but there was no apparent balding at six weeks.

One cephalhæmatoma occured, giving an incidence of $3 \%$. This is a much lower incidence than that recorded by Huntingford (196r).

The important complication associated with the technique is cerebral irritation (Table 5). In two infants of primiparæ, this was of a mild nature, increased tone being noted which required cot-nursing for 48 hours. Both deliveries were completed by forceps. Over an hour's traction was needed to achieve full dilatation in one instance, this being followed by easy rotation but difficult extraction with Kielland's forceps. Detachment of the cup occurred in the other case, on commencing firm traction after full dilatation, so Kielland rotation and forceps delivery was necessary. Holtorff (196r), in a follow-up study of fœtal mortality and morbidity following delivery with forceps and vacuum extraction, finds that some disappointments will occur: cerebral 
TABLE 5

Details of Cases with Cerebral Irritation

\begin{tabular}{|c|c|c|c|c|c|c|c|c|}
\hline Parity & Indication & $\begin{array}{c}\text { Length of } \\
\text { Labour }\end{array}$ & $\begin{array}{l}\text { Duration of } \\
\text { Traction }\end{array}$ & $\begin{array}{l}\text { Birth } \\
\text { Weight }\end{array}$ & Scalp & $\begin{array}{l}\text { Condition } \\
\text { at Birth }\end{array}$ & Progress & Follow-up \\
\hline 0 & $\begin{array}{l}\text { Static at } \frac{1}{2} \text { dilata- } \\
\text { tion }\end{array}$ & 29 hours & $\begin{array}{l}\text { Approxi- } \\
\text { mately } 40 \\
\text { minutes }\end{array}$ & 7.12 & $\begin{array}{l}\text { Abrasion. Small } \\
\text { slough }\end{array}$ & $\begin{array}{l}\text { White } \\
\text { asphyxia }\end{array}$ & $\begin{array}{l}\text { Increased } \\
\text { tone. Cot } \\
\text { nursed } 24 \mathrm{hrs} .\end{array}$ & $\begin{array}{l}\text { Bald patch. } \\
\text { Normal de- } \\
\text { velopment. }\end{array}$ \\
\hline 0 & $\begin{array}{l}\text { Prolonged labour } \\
\text { occipito-posterior } \\
\text { position. Under } \\
6 \mathrm{~cm} \text {. dilated. }\end{array}$ & 44 hours & 70 minutes & 8.4 & $\begin{array}{l}\text { Bruised caput. } \\
\text { Scabbing. }\end{array}$ & Good & $\begin{array}{l}\text { High pitched } \\
\text { cry. Increased } \\
\text { tone }\end{array}$ & $\begin{array}{l}\text { Bald patch. } \\
\text { Normal de- } \\
\text { velopment. }\end{array}$ \\
\hline 2 & $\begin{array}{l}\text { Delay, cervix thick } \\
\text { under } 6 \mathrm{~cm} \text {. dilated } \\
\text { Mild aortic steno- } \\
\text { sis. }\end{array}$ & I9 hours & 40 minutes & 7.14 & $\begin{array}{l}\text { Minimal } \\
\text { abrasion }\end{array}$ & $\begin{array}{l}\text { Blue } \\
\text { asphyxia. } \\
\text { Slow to } \\
\text { cry. }\end{array}$ & $\begin{array}{l}\text { Twitching of } \\
\text { right side. } \\
\text { Sedation. } \\
\text { Satisfactory } \\
\text { at } 6 \text { days. }\end{array}$ & $\begin{array}{l}\text { Normal at } 5 \\
\text { months. } \\
\text { Backwards at } \\
\text { I } 9 \text { months } \\
\text { ? Right hemi- } \\
\text { paresis. }\end{array}$ \\
\hline
\end{tabular}

irritation is particularly liable when both vacuum extractor and forceps are used on the same child.

Serious cerebral irritation occured once. The head was above the spines and well flexed in a posterior position. A good application was obtained with the small cup at 5 to $6 \mathrm{~cm}$. dilatation. Little further dilatation occurred during the first half hour of traction and the patient was rather restless, complaining of pain and cramp in the right leg. Delivery occurred after 40 minutes of traction. Although the infant's breathing was regular at birth, the cry was poor and, the following day, signs of cerebral irritation were present and right-sided twitching necessitated sedation. Progress seemed normal at five months, but at I9 months he was not walking or talking and a right hemiparesis is probable.

\section{Maternal Complications}

The vacuum extractor is considered very safe for the mother and free from soft tissue damage (Chalmers and Fothergill, I960; Smedley, 1960). It will be noted that vaginal laceration occured twice in this series (Table 6), on both occasions causing postpartum hæmorrhage. The lacerations were attributable to the subsequent Kielland rotation and forceps deliveries. The twin delivery complicated by intrapartum hæmorrhage also had a small postpartum hæmorrhage. The forcible cervical dilatation did not cause cervical tears and Dührssen's incisions were never considered.

The only other relative maternal complication was a peroneal nerve palsy, which has not been recorded previously. The lithotomy position was maintained for about $I \frac{1}{2}$ hours, with the legs outside the poles, and traction continued intermittently for 40 minutes. During this time, the patient complained of severe pain in the right leg. Since her previous children had similar birth
TABLE 6

Maternal Complications

Postpartum hæmorrhage .. 3 (2 from lacerations)

Vaginal laceration $\quad$. . 2

Manual removal of placenta I

Peroneal nerve palsy $\quad . . \quad$ I

Puerperal pyrexia

Puerperal psychosis

.. $\quad$ I (urinary tract infection) .. I

TABLE 7

INDicAtions FOR APPLICATION OF ForCePS

\begin{tabular}{|c|c|c|}
\hline Indications & $\begin{array}{c}\text { Occipito-posterior } \\
\text { and Transverse } \\
\text { Position }\end{array}$ & $\begin{array}{l}\text { Anterió } \\
\text { Position }\end{array}$ \\
\hline Failed ventouse rotation & 3 & 0 \\
\hline $\begin{array}{l}\text { Minor disproportion, } \\
\text { posterior position }\end{array}$ & 4 & 0 \\
\hline Fœtal distress .. $\ldots$ & 2 & $\mathbf{I}$ \\
\hline Detachment ventouse... & I & I \\
\hline $\begin{array}{crr}\text { Failed traction } & \text { with } \\
\text { ventouse } & \ldots & \ldots\end{array}$ & 0 & 3 \\
\hline Rigid perineum & 0 & I \\
\hline Elective & I & 0 \\
\hline & I I & 6 \\
\hline
\end{tabular}

weights and no local pressure on the nerve $\widetilde{N}$ occurred, the lesion must have been due to $N$ pressure on the lumbosacral cords by the descend- N ing fotal head. Cole (1946) believes the pelvis must have certain characteristics for this to occur: these are a flat sacral promontory, shallow sacral $\underset{\mathbb{D}}{\leftarrow}$ alæ, and a short posterior portion of the iliac $\stackrel{\mathscr{\infty}}{?}$ bones.

Forceps were applied after full dilatation in I7 cases, probably an unnecessarily high figure 
TABLE 8

Prolonged Labour (Over 36 Hours)

Number of Cases 54. Percentage of all deliveries $1.2 \%$

\begin{tabular}{|c|c|c|}
\hline Method of Delivery & Number of Cases & Percentage \\
\hline Cæsarean section & I I & $20.4 \%$ \\
\hline Forceps delivery & 16 & $29.8 \%$ \\
\hline Vacuum extraction .. & 7 & $13.0 \%$ \\
\hline Spontaneous delivery & I 9 & $35.1 \%$ \\
\hline Breech extraction & $\mathbf{I}$ & $1.7 \%$ \\
\hline
\end{tabular}

(Table 7). The failures were mostly with posterior positions, although this is one of the main indications listed by Willcocks (I962) for the use of the ventouse in the second stage of labour. As traction was prolonged before reaching full dilatation in several instances, it was felt that the duration of the second stage should be limited. Of course, there were also failures from cup detachment and forceps were therefore applied.

The value of vacuum extraction is also apparent in dealing with prolonged labour, itself a rare occurrence (Table 8). Spontaneous deliveries occur, following adequate sedation and hydration, in a considerable proportion of cases, $35 \%$ in this series and $24 \%$ in a series reported by Jeffcoate (I96I). Cæsarean section was performed II times; in seven, vacuum extraction had been considered but was rejected as some disproportion was evident. In another seven cases vaginal delivery was thought possible and was effected, labour lasting from 39 to 53 hours and dilatation varying from over 3 fingers to a rim all round.

\section{Discussion}

The value of the vacuum extractor as an alternative to Cæsarean section and the results obtained both from forceps and from vacuum extraction will be discussed from the fotal and maternal aspects.

Most obstetricians, reporting on the ventouse, agree that one great advantage of this instrument is that it may safely be used to expedite delivery, prior to full dilatation of the cervix. Some consider that the degree of cervical dilatation is unimportant (Lillie, 1960), others that the cervix should be about $5 \mathrm{~cm}$. dilated prior to application of the instrument (Bruniquel and Isræl, 1958; Snoeck, 1960), and Chalmers (1960) considers that the vacuum extractor is best used when the cervix is three-quarters dilated although he has used it at lesser dilatations. The ventouse effected full dilatation, if not delivery, in all our cases, the dilatation being from $3 \mathrm{~cm}$. upwards. However the object is not only vaginal delivery but birth of an unharmed infant. Therefore, use of the ventouse is only justified if the results obtained are as good as or better than Cæsarean section from all aspects.

Alarming fotal results following vacuum extraction for delay in the first stage of labour were reported by Huntingford (196r). Two neonatal deaths occurred in I I deliveries. One resulted from intracranial hæmorrhage, apparently related to the application of the ventouse. The second neonatal death demonstrated another hazard of this method, viz. unsuspected disproportion necessitating Cæsarean section. The baby died of atelectasis from meconium aspiration. Four other infants showed cerebral irritation, the traction time varying from 25 to 75 minutes. Huntingford, therefore, advised 'cautious appraisal' of the use of the vacuum extractor for delay in the first stage.

Evidence from the series reported in this paper suggests that the incidence of significant scalp trauma and cerebral damage is related to the duration of traction. This was 40 minutes or over in all cases affected. It would therefore seem wise to limit traction to 30 minutes as suggested by Willcocks (1962) and Lauridsen, Pless, and Uhrenholdt (1962). As the traction time is also related to the degree of cervical dilatation (Table 3 ) the ventouse should seldom be applied before one-half dilatation in multigravidæ and not till over one-half dilatation in primigravidæ.

The majority of minor abrasions heal without infection, prior to discharge from hospital. Lauridsen and others (1962), following up infants after vacuum extraction, found slight pigmentation of the scalp in three, and an area of alopecia in one of 15 cases of minor abrasions. The danger from potential infection mentioned by Huntingford (196r) is lessened in this hospital by the practice of giving antibiotics to all infants born 48 hours or more after rupture of the membranes, a routine affecting a number of the cases treated by vacuum extraction.

Neonatal deaths from intracranial hæmorrhage, associated with vacuum extraction, have been recorded by many authors (Hochuli and Stöckli, 1960; Snoeck, 1960; Holtorff, 196r ; Huntingford, r96r; and Willcocks, 1962). The stage of labour in which the ventouse was applied was not always recorded and, in some, intra-uterine anoxia was partly responsible.

Cerebral irritation was noted by Fürstenberg and Söderhjelm (1960), Huntingford (196r), and Willcocks (1962). Holtorff (196r) found that it is particularly liable to occur if forceps are applied after the ventouse, which agrees with our experience. The one case of definite cerebral damage reported in the present series had no 
TABle 9

Cerebral Trauma Associated with Vacuum EXTRACTION

\begin{tabular}{|c|c|c|c|c|}
\hline Authors & Cases & \begin{tabular}{|c|} 
Neo- \\
natal \\
deaths
\end{tabular} & $\begin{array}{l}\text { Deaths from } \\
\text { intracranial } \\
\text { hæmorrhage }\end{array}$ & $\begin{array}{l}\text { Cerebral } \\
\text { irritation }\end{array}$ \\
\hline $\begin{array}{l}\text { Fürstenberg and } \\
\text { Söderhjelm } \\
\text { (1960) }\end{array}$ & 67 & I & $\circ$ & 4 \\
\hline $\begin{array}{rr}\text { Hochuli } & \text { and } \\
\text { Stöckli } & \text { (1960) }\end{array}$ & 265 & 3 & 2 & $\begin{array}{l}\text { Not } \\
\text { recorded }\end{array}$ \\
\hline Holtorff (196I) & 119 & 2 & $\mathbf{I}$ & $\begin{array}{l}\text { Not } \\
\text { recorded }\end{array}$ \\
\hline$\underset{(196 I)}{\text { Huntingford }}$ & I I & 2 & I & 4 \\
\hline 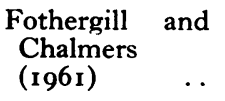 & 200 & 2 & 2 & $\circ$ \\
\hline Willcocks (1962) & 100 & 3 & $\mathbf{I}$ & 3 \\
\hline $\begin{array}{l}\text { Lauridsen and } \\
\text { others }(1962) .\end{array}$ & 69 & $\circ$ & $\circ$ & $\circ$ \\
\hline Present series & 32 & ० & $\circ$ & 3 \\
\hline
\end{tabular}

counterpart in a follow-up study by Lauridsen and others (1962), or in the pædiatricians' follow-up of Willcocks' series ( 1962 ).

The real dangers to the fœetus, then, are possible intracranial hæmorrhage or cerebral damage, which, in recorded series (Table 9) have a very low incidence. Although de Boer (1960) has shown that the ventouse will raise the intracranial pressure, evidently a harmful effect is seldom produced.

There is a well-defined group of primigravidæ who become post-mature with an occipitoposterior position and who often commence labour with rupture of the membranes. The contractions that follow are ineffectual or progress becomes arrested and maternal or fotal distress develops. Prior to the introduction of the ventouse, Cæsarean section was necessary, with its attendant risks to the fœtus of central depression from general anæsthesia and pulmonary complications. Now, with judicious use of the ventouse, it is possible to deliver these patients with inertia or prolonged labour vaginally and often prior to the development of fotal distress, providing that there is no clinical evidence of disproportion.

Multiparæ in established labour, with fœtal distress, can be delivered rapidly with the ventouse, again without resorting to general anæsthesia.

Considerable difficulty may be experienced in securing premature delivery in cases of Rhesus incompatibility. The ventouse has been used to advantage on two occasions when surgical induc- tion and Syntocinon infusion have failed to establish progressive labour.

The overall safety of the vacuum extractor for $\stackrel{D}{2}$ delivery is confirmed by Bergman and Malström (1961). Analysing the $195^{8}$ records of 29 Swedish $\stackrel{\vec{F}}{\stackrel{7}{9}}$ Hospitals, they found that in 44,767 vertex $\frac{7}{0}$ deliveries the fotal mortality was $4.1 \%$ for 793 음 forceps deliveries compared with only $\mathrm{I} .5 \%$ for $\overline{\bar{c}}$ vacuum extraction. The greater safety of applica- $\mathbb{\otimes}$ tion of the vacuum extractor in mid or high 2 pelvis was also demonstrated. In addition, fatal ${ }^{\circ}$ intracranial injury occurred in only $0.7 \%$ of $\vec{\circ}$ deliveries with the instrument compared with $\overrightarrow{\vec{H}}$ $1.5 \%$ for forceps. From our figures (Table I), $\stackrel{\circ}{\circ}$ it is seen that the uncorrected fœtal mortality $\overrightarrow{0}$ associated with Cæsarean section and forceps 3 extraction are considerable, $6.5 \%$ and $4.2 \%$ respectively, but that there was no mortality after use of the ventouse.

There are only two reported maternal deaths associated with vacuum extraction and neither 0 death was related to the mode of delivery. $\frac{}{7}$ Cæsarean section, however, has a maternal $\vec{\sim}$ mortality of at least $0.33 \%$ (Report on Confidential Enquiries into Maternal deaths, 1960), death being mainly due to hæmorrhage and shock, pulmonary $\stackrel{\oplus}{\rightarrow}$ embolism, sepsis and ileus, or anæsthesia. Vacuure $\overrightarrow{\mathscr{Q}}$ extraction, which causes no damage to the so tissues, makes no further demands on the materne reserves, which are already depleated in cases of prolonged labour and maternal distress. This is not true of Cæsarean section, to which the dangers from anæsthesia and blood loss are added and $\stackrel{\circ}{\varnothing}$ convalescence may be impaired by infection or $\stackrel{2}{\Rightarrow}$ pulmonary complications.

The use of local anæsthesia for vacuum extraction allows voluntary effort of the mother to assist delivery when full dilatation is reached, particularly in multiparæ. The second stage is completed $\underline{3}$ in ten minutes in the majority of cases. However, the lithotomy position is not comfortable for the long periods of time necessary in some cases. \& One patient, who was in the position for just under two hours, subsequently said her worst 을 memory was of the long labour prior to inter- $\rightarrow$ ference. If, in future, the vacuum extractor is only used when the anticipated time to achieve $N$ delivery is less than 40 minutes, this disadvantage will be eliminated. The rare complication of a $\tilde{o}$ peroneal nerve palsy must have been related to $\underset{\omega}{N}$ traction applied with the head in the oblique posterior position. This palsy may even follow spontaneous delivery (Chassar Moir, 1956).

Huntingford's (I96I) suggestion that the forcible cervical dilatation may be followed by cervical $\frac{0}{\circ}$ incompetence is of interest. So far no case has $\underset{\mathbb{D}}{\stackrel{\circ}{\mathbb{N}}}$ been encountered here. 


\section{Conclusions}

I. The vacuum extraction is an effective method of treating complications of the first stage of labour.
2. The risks to mother and child are less than either Cæsarean section or forceps delivery.

I would like to acknowledge the encouragement and advice given by Mr. A. L. Gunn and Mrs. J. Karnicki.

\section{REFERENCES}

Alment, E. A. J. (1960): The Vacuum Extractor (Ventouse)-An Alternative to the Obstetric Forceps, Proc. Roy Soc. Med., 53, 759 .

Bergman, P., and MaLström, T. (1961): Vacuum Extraktor eller Forceps, Nord. Med., 65, 644.

Bruniouel, G. and IsRaEL, A. (1958): Contributions e, etud. de la Ventouse Obstetricale son Champ d'Application, ses Avantages, Gynéc. et Obstét., 57, 222.

Chalmers, J. A. (1960): The Vacuum Extractor (Ventouse)-An Alternative to the Obstetric Forceps, Proc. Roy. Soc. Med., 53, 753 .

— and FothERGILL, R. J. (1960): Use of a Vacuum Extractor (Ventouse) in Obstetrics, Brit. med. F., i, 1684.

Chassar Moir, J. (1956): 'Munro Kerr's Operative Obstetrics'. London: Baillière, Tindall and Cox.

Cole, J. T. (1946): Maternal Obstetric Paralysis, Amer. F. Obstet. Gynec., 52, 372.

DE BOER, C. H. (1960): The Vacuum Extractor (Ventouse)-An Alternative to the Obstetric Forceps, Proc. Roy. Soc. Med., 53, 758.

Fothergill, R. J., and Chalmers, J. A. (196I): The Place of the Ventouse (Vacuum Extractor) in Domiciliary Practice, Practitioner, 186, 559.

Fürstenberg, N., and SöDURhjelm, L. (1960): Vacuum Extraktionens Verkau pa Barnen, Nord. Med., 64, 843.

Hochulı, E., and STöcKLI, A. (1960): Erfahrungen mit dem Vakuumestraktor nach Malstroem bei 265 Fällen, Geburtsh. u. Frauenheilk, 20, 346.

HoltorfF, J. (I961): Die Kindliche Mortalität und Morbidität bei Zangen- und Vakuumextrationen, Zbl. Gynäk., 83,261 .

Huntingford, P. J. (1961): The Vacuum Extractor in the Treatment of Delay in the First Stage of Labour, Lancet, ii, 1054.

JefFcoate, T. N. A. (I96I): Prolonged Labour, Lancet, ii, 6r.

Lauridsen, L., Pless, J., and Uhrenholdt, A. (1962): Vacuum-extraction, a Follow-up Study, f. Obstet. Gynac. Brit. Cwlth., 69, ro19.

Lillie, E. W. (1960): The Vacuum Extractor (Ventouse)-An Alternative to the Obstetric Forceps, Proc. Roy. Soc. Med., 53, 758 .

MaLsTröM, T. (1954): The Vacuum Extractor. An Obstetrical Instrument, Act x obstet. gynoc. scand., 33, suppl. 4.

MALSTRöM, T. (1957): The Vacuum Extractor. An Obstetrical Instrument, Ibid., 36, suppl. 3.

'Report on Confidential Enquiries into Maternal Deaths in England and Wales, 1955-1957' (1960). London: H.M. Stationery Office.

Simpson, J. Y. (1849): On a Suction-Tractor, or New Mechanical Power, as a Substitute for the Forceps in Tedious Labours, Proc. Edinb. Medico-Chir. Soc., 556.

Smedley, G. T. (1960): The Vacuum Extractor (Ventouse)-An Alternative to the Obstetric Forceps, Proc. Roy. Soc. Med., 53, 757 .

SNOECK, J. (1960): Ibid., 53, 749.

'Standard Form Recommended by the Royal College of Obstetricians and Gynæcologists for the Production of Maternity Hospital Medical Reports' (1957): f. Obstet. Gynac. Brit. Emp., 64, 752.

Willcocks, J. (1962): The Vacuum Extractor-An Evaluation, f. Obstet. Gynac. Brit. Cwlth., 69, 267. 